\title{
Структура популяцій клена гостролистого в умовах Кролевецько-Глухівського геоботанічного району
}

Розглянуто онтогенетичну структуру ценопопуляцій Acer platanoides у дев’яти угрупованнях лісової рослинності, типових для Кролевецько-Глухівського геоботанічного району. Визначено характерні ознаки онтогенетичних спектрів Acer platanoides в умовах Кролевецько-Глухівського геоботанічного району. Установлено основні тенденції щодо зміни стану ценопопуляцій та їхніх онтогенетичних характеристик в умовах Кролевецько-Глухівського геоботанічного району. район.

Ключові слова: лісові фітоценози, популяції, клен гостролистий, Кролевецько-Глухівський геоботанічний

Постановка наукової проблеми та її значення. До регіонів із досить високими показниками залісненості належить Кролевецько-Глухівський геоботанічний район. Лісові фітоценози вкривають близько $11 \%$ його території [1]. Кролевецько-Глухівський геоботанічний район входить до Середньоросійської підпровінції. В адміністративному плані він уключає Глухівський, Кролевецький, Путивльський райони Сумської області. На основі флористичних досліджень території КролевецькоГлухівського геоботанічного району та задля оптимізації природно-заповідного фонду регіону в межах Кролевецького району підготовлено й подано до Державного управління екобезпеки України в Сумській області наукове обгрунтування для створення заказника «Артюхівський» місцевого значення з наданням йому статусу регіонального центру біорізноманіття [2].

Ліси цієї місцевості мають велике еколого-стабілізаційне значення як для самого КролевецькоГлухівського геоботанічного району, так і для прилеглих територій. Крім того, вони - важливі осередки біорізноманіття, у тому числі як місце існування низки раритетних видів рослин і тварин [3; 4].

На території Кролевецько-Глухівського геоботанічного району найбільшу частку лісового фонду представлено широколистяними лісами. Основним лісоутворювальним видом тут є дуб звичайний (Quercus robur L.) [1, 5]. Однак сьогодні важливу роль у складі лісів відіграє клен гостролистий (Acer platanoides L.), який у майбутньому може змінити лісові насадження цього регіону.

Кількісні та якісні ознаки ценопопуляцій $A$. platanoides можуть виступати одними 3 чітких індикаторів еколого-ценотичних взаємодій, притаманних тому чи іншому фітоценозу, свідченнями його здатності до сталого існування, а також можливості прояву сукцесійних змін. Відповідно, вивчення стану ценопопуляцій A. platanoides у різних лісових угрупованнях Кролевецько-Глухівського геоботанічного району є доцільне та актуальне. Тим більше, що в цьому регіоні провідні лісоутворювальні види ще недостатньо охоплені популяційним аналізом.

Мета роботи - оцінити онтогенетичну структуру ценопопуляцій A. platanoides у лісових угрупованнях, що є типовими для Кролевецько-Глухівського геоботанічного району.

Матеріал і методи досліджень. Дослідження проводили в період 2012-2015 рр. Ним охоплено такі лісові угруповання: 1. Querceto (roboris)-Aceretum (platanoiditis) aegopodiosum (podagrariae), 2. Tilieto (cordatae)-Aceretum (platanoiditis) urticosum (dioici), 3. Tilieto (cordatae)-Acereto (platanoiditis)-Quercetum aegopodioso (podagrariae)-caricosum (pilosae), 4. Quercetum (roboris) convallariosum (majalis), 5. Tilieto (cordatae)-Acereto (platanoiditis)-Quercetum (roboris) aegopodiosum (podagrariae), 6. Acereto (platanoiditis) Quercetum (roboris) coryloso (avellanae)-aegopodiosum (podagrariae), 7. Querceto (roboris)-Tilieto (cordatae) Acereto (platanoiditis)-Betuletum (pendulae) stellarioso (holosteae)-caricosum (pilosae), 8. Fraxineto (excelsioris)-Tilieto (cordatae)-Querceto (roboris)-Aceretum (platanoiditis) urticoso (dioici)-aegopodiosum (podagrariae), 9. Quercetum (roboris) aegopodiosum (podagrariae). Усі вони типові для КролевецькоГлухівського геоботанічного району.

У зазначених фітоценозах відповідно до загальноприйнятих вимог оцінено частку рослин різних онтогенетичних станів [6-10]. При цьому належність особин до певного етапу розвитку визначали, ураховуючи комплекс ознак, наведених нижче.

Проростки (р) - рослини A. platanoides, у яких наявні надземні сім'ядолі та пара справжніх листків.

Ювенільні рослини (j) - особини без галуження, що несуть 1-4 пари листків, які є пальчастими, інколи - трійчастими й вирізняються незначною глибиною розчленування пластинки.

(C) Дегтярьов В., 2015 
Рослини імматурного онтогенетичного стану (im) здебільщого мають висоту від 0,5 см до 2,5 м та 1-4 порядки галуження.

Віргінільні рослини (v) - молоді дерева, що набули характерної для дорослих рослин морфологічної структури, однак ще не вступили у фазу цвітіння й плодоношення.

Генеративні рослини (g) - дерева, які вступили у фазу формування структур генеративного розмноження.

Молоді генеративні рослини $\left(\mathrm{g}_{1}\right)$ звичайно мають гостровершинну крону. У покривних тканинах основи їхнього стовбура наявні тріщини.

Середньогенеративні $\left(\mathrm{g}_{2}\right)$ дерева формують туповерхівкову крону, рясно плодоносять, повільно ростуть у висоту й досить швидко - у товщину. Тріщини в покривних тканинах досягають майже середини висоти стовбура.

Для старих генеративних $\left(\mathrm{g}_{3}\right)$ рослин характерна широкоокругла крона, ріст у висоту практично завершений. Майже по всій довжині стовбур укритий тріщинами.

Сенільні рослини (s) - дерева, які не плодоносять, усихають і мають вторинну крону.

Онтогенетичні спектри ценопопуляцій A. platanoides проаналізовано в аспекті їх належності до одного 3 чотирьох типів: лівосторонні, що вирізняються домінуванням догенеративних особин, центровані, які переважають генеративних особин, правосторонні, для котрих притаманна висока кількість сенільних рослин, бімодальні, що мають два пікових значення.

На завершальному етапі досліджень визначали належність ценопопуляцій кожного угруповання до певної категорії відповідно до класифікації Т. О. Работнова: інвазійні - популяції, у складі котрих переважають догенеративні особини; нормальні, у яких переважають генеративні рослини; регресивні, у складі котрих більше постгенеративних особин [11].

Виклад основного матеріалу й обгрунтування отриманих результатів дослідження. Результати досліджень, узагальнені в таблиці 1, засвідчують, що в умовах Кролевецько-Глухівського геоботанічного району A. platanoides зростає в складі різноманітних лісів: мішаних, дрібнолистяних та широколистяних, але найбільше їх трапляється в широколистяних лісах. Загалом здатність цього виду впроваджуватися до різних типів фітоценозів й успішно поширюватися по території відзначають науковці й для інших регіонів світу [12-14]. Цьому сприяють притаманні A. platanoides швидкий ріст, стійкість до шкідників, конкурентотолерантний тип популяційної поведінки, поліваріантність онтогенезу та утворення великої кількості плодів, що відносяться вітром на значні відстані від материнських особин [15-16].

Таблиия 1

\section{Онтогенетична структура ценопопуляцій Acer platanoides у різних угрупованнях Кролевецько-Глухівського геоботанічного району}

\begin{tabular}{|c|c|c|c|c|c|c|c|c|}
\hline \multirow[t]{2}{*}{ Угруповання } & \multicolumn{8}{|c|}{$\begin{array}{c}\text { Онтогенетичні стани рослин та їх частка (\%) у складі } \\
\text { ценопопуляції }\end{array}$} \\
\hline & $\mathbf{p}$ & $\mathbf{j}$ & im & $\mathbf{v}$ & $\mathbf{g}_{1}$ & $\mathbf{g}_{2}$ & $\mathbf{g}_{3}$ & $\mathbf{s}$ \\
\hline 1 & 2 & 3 & 4 & 5 & 6 & 7 & 8 & 9 \\
\hline $\begin{array}{l}\text { Querceto (roboris)-Aceretum (platanoiditis) } \\
\text { aegopodiosum (podagrariae) }\end{array}$ & 3,4 & 11,4 & 50,9 & 11,1 & 17,6 & 5,6 & 0 & 0 \\
\hline $\begin{array}{l}\text { Tilieto (cordatae)-Aceretum (platanoiditis) } \\
\text { urticosum (dioici) }\end{array}$ & 0 & 0 & 33,3 & 44,4 & 22,3 & 0 & 0 & 0 \\
\hline Quercetum (roboris) convallariosum (majalis) & 6,6 & 17,9 & 75,5 & 0 & 0 & 0 & 0 & 0 \\
\hline $\begin{array}{l}\text { Tilieto (cordatae)-Acereto (platanoiditis)- } \\
\text { Quercetum aegopodioso (podagrariae)-caricosum } \\
\text { (pilosae) }\end{array}$ & 0 & 0 & 0 & 100 & 0 & 0 & 0 & 0 \\
\hline $\begin{array}{l}\text { Acereto (platanoiditis)-Quercetum (roboris) } \\
\text { coryloso (avellanae)-aegopodiosum (podagrariae) }\end{array}$ & 25,1 & 18,8 & 30,6 & 11,7 & 9,1 & 4,7 & 0 & 0 \\
\hline $\begin{array}{l}\text { Tilieto (cordatae)-Acereto (platanoiditis)- } \\
\text { Quercetum (roboris) aegopodiosum (podagrariae) }\end{array}$ & 11,9 & 5,5 & 73,4 & 5,5 & 3,7 & 0 & 0 & 0 \\
\hline Quercetum (roboris) aegopodiosum (podagrariae) & 8,7 & 15,2 & 76,1 & 0 & 0 & 0 & 0 & 0 \\
\hline
\end{tabular}


РОЗДІЛ І. Ботаніка. 12, 2015

\begin{tabular}{|c|c|c|c|c|c|c|c|c|}
\hline \multicolumn{9}{|c|}{ Закінчення таблиці } \\
\hline 1 & 2 & 3 & 4 & 5 & 6 & 7 & 8 & 9 \\
\hline $\begin{array}{l}\text { Fraxineto (excelsioris)-Tilieto (cordatae)-Querceto } \\
\text { (roboris)-Aceretum (platanoiditis) urticoso (dioici)- } \\
\text { aegopodiosum (podagrariae) }\end{array}$ & 9,4 & 0 & 58,2 & 0 & 0 & 32,4 & 0 & 0 \\
\hline $\begin{array}{l}\text { Querceto (roboris)-Tilieto (cordatae)-Acereto } \\
\text { (platanoiditis)-Betuletum (pendulae) stellarioso } \\
\text { (holosteae)-caricosum (pilosae) }\end{array}$ & 15,1 & 0 & 64,4 & 0 & 20,5 & 0 & 0 & 0 \\
\hline
\end{tabular}

Для Кролевецько-Глухівського геоботанічного району характерне формування ценопопуляцій A. platanoides iз неповними онтогенетичними спектрами, у складі яких відсутні рослини 2-7 онтогенетичних станів.

У лісах Кролевецько-Глухівського геоботанічного району в майже всіх фітоценозах наявні генеративні рослини A. platanoides. Виняток становить лише ценопопуляція з угруповання Tilieto (cordatae)-Acereto (platanoiditis)-Quercetum aegopodioso (podagrariae)-caricosum (pilosae), на $100 \%$ сформована $з$ віргінільних рослин. Незважаючи на зазначені особливості, загалом у лісах Кролевецько-Глухівського геоботанічного району широко представлені ценопопуляції A. platanoides категорії інвазійних із лівосторонніми онтогенетичними спектрами. У їх складі найбільшу частку $(50,9-73,4 \%)$ становлять імматурні або віргінільні (44,4-100 \%) рослини.

В угрупованнях Quercetum (roboris) convallariosum (majalis), Acereto (platanoiditis)-Quercetum (roboris) coryloso (avellanae)-aegopodiosum (podagrariae), Quercetum (roboris) aegopodiosum (podagrariae), онтогенетичні спектри A. platanoides є несиметричними, лівосторонніми, а самі популяції належать до категорії інвазійних. Тут в абсолютній більшості лісових фітоценозів A. platanoides не досягає генеративної стадії й припиняє свій розвиток в імматурному або, рідше, - віргінільному онтогенетичному стані.

Характер представленості в низці фітоценозів (Tilieto (cordatae)-Aceretum (platanoiditis) urticosum (dioici Tilieto (cordatae)-Acereto (platanoiditis)-Quercetum aegopodioso (podagrariae)-caricosum (pilosae), Fraxineto (excelsioris)-Tilieto (cordatae)-Querceto (roboris)-Aceretum (platanoiditis) urticoso (dioici)-aegopodiosum (podagrariae), Querceto (roboris)-Tilieto (cordatae)-Acereto (platanoiditis)-Betuletum (pendulae) stellarioso (holosteae)-caricosum (pilosae)) особин A. platanoides різних онтогенетичних станів указує на те, що в часі процес упровадження до складу лісових угруповань цього виду є неоднаково успішним. Унаслідок коливання за роками погодних показників, а також рівня насіннєвої продуктивності в регіоні в лісоутворювальних видів проявляються «хвилі» природного поновлення. Це супроводжується «випадінням» зі спектрів рослин певних онтогенетичних станів або, навпаки, «піковим» збільшенням їх частки.

Кролевецько-Глухівський геоботанічний район має високий рівень родючості грунтів, радіаційного балансу та температурних показників і, в підсумку, - високу відповідність умов місцезростань екологічним вимогам цього виду. Це, безумовно, сприяє успішнішому онтогенетичному розвиткові A. platanoides i досягненню його особинами генеративного онтогенетичного стану. Однак ліси Кролевецько-Глухівського району є багатоярусними, мають розвинений підлісок $\mathrm{i}$, як наслідок, меншу освітленість під їхнім наметом. Зазначена особливість ускладнює формування, а також ріст і розвиток проростків та ювенільних рослин. Тому як на початкових етапах онтогенезу серед провідних лісоутворювальних видів A. platanoides посідає перші місця в шкалах світлолюбності [17].

Виходячи із сучасних особливостей онтогенетичної структури ценопопуляцій A. platanoides, уважаємо, що в майбутньому для лісів Кролевецько-Глухівського геоботанічного району не буде характерним зменшення представленості цього виду в складі фітоценозів регіону. Навпаки, цілком можливе зростання частки A. platanoides у деревостанах, угруповань Tilieto (cordatae)-Acereto (platanoiditis)-Quercetum aegopodioso (podagrariae)-caricosum (pilosae)та Querceto (roboris)-Tilieto (cordatae)-Acereto (platanoiditis)-Betuletum (pendulae) stellarioso (holosteae)-caricosum (pilosae), Quercetum (roboris) aegopodiosum (podagrariae), Quercetum (roboris) convallariosum (majalis).

Перспективою подальших наукових досліджень $є$ організація на території Кролевецько-Глухівського геоботанічного району моніторингу за станом лісових фітоценозів, у тому числі й тих, де зростає A. platanoides. Насамперед таким вивченням повинні бути охоплені угруповання, які вважаються осередками раритетного біорізноманіття. Це дасть змогу поглибити знання про онтогенетичний розвиток у регіоні особин усіх основних лісоутворювальних видів, визначити характерні 
ознаки стану популяцій, скласти прогнози зміни лісових фітоценозів, а також оптимізувати їх охорону та систему природокористування.

Висновки й перспективи подальшого дослідження. За результатами проведених досліджень установлено, що в лісових фітоценозах Кролевецько-Глухівського геоботанічного району здебільшого представлені ценопопуляції A. platanoides, онтогенетичні спектри яких є неповними за наявністю рослин різних станів. Це - результат складної взаємодії природних й антропогенних чинників. У першому аспекті визначальний прояв «хвиль поновлення». У другому - ведення лісового господарства, що передбачає проведення в лісах вирубок (суцільних або вибіркових) до досягнення деревами сенільного онтогенетичного стану та навіть стадії старих генеративних $\left(\mathrm{g}_{3}\right)$ особин.

Для регіону досліджень типові ценопопуляції A. platanoides категорії інвазійних, що мають мономодальні лівосторонні онтогенетичні спектри.

\section{Джерела та література}

1. Снігур М. Я. Ліси Сумщини, їх значення, використання та охорона / Я. М. Снігур // Стан природного середовища та проблеми його охорони на Сумщині : збірник / голов. ред. К. К. Карпенко. - Суми : ВЦ ДІМ, 1996. - Кн.1. - С. 60-69.

2. Геоботанічне районування Української РСР // [Т. Л. Андрієнко, Г. І. Білик, Є. М. Брадіс та ін.]. - К. : Наук. думка, 1977. - 302 с.

3. Заповідні скарби Сумщини / [Т. Л. Андрієнко та ін. ] ; під заг. ред. Т. Л. Андрієнко. - Суми : Джерело, 2001. - 208 c.

4. Фіторізноманіття Українського Полісся та його охорона / [наук. ред. Т. Л. Андрієнко]. - К. : Фітосоціоцентр, 2006. - 316 с.

5. Карпенко К. К. Рослинність Сумської області, її сучасний стан і проблеми охорони / К. К. Карпенко, В. А. Ковтун // Стан природного середовища і проблеми його охорони на Сумщині. - Суми : Вид. центр «Дім», 1996. - С. 33-59.

6. Диагнозы и ключи возрастных состояний лесных растений. Деревья и кустарники / [А. А. Чистякова, Л. Б. Заугольнова, И. В. Полтинкина и др.] ; под ред. О. В. Смирновой. - М. : Прометей, 1989. - 102 с.

7. Евстигнеев О. И. Онтогенез сосны обыкновенной в разных экологических условиях Неруссо-Деснянского Полесья / О. И. Евстигнеев, Н. А. Татаренкова // Деп. во ВНИИЦлесресурс. - № 933-лх. - М., 1995. $-47 \mathrm{c}$.

8. Животовский Л. А. Онтогенетические состояния, эффективная плотность и классификация популяций растений / Л. А. Животовский // Экология. - 2001. - № 1. - С. 3-7.

9. Смирнова О. В. Онтогенез дерева и его отражение в структуре и динамике растительного и почвенного покрова / О. В. Смирнова, М. В. Бобровский // Экология. - 2001. - № 3. - С. 177-181.

10. Злобин Ю. А. Популяционная экология растений: современное состояние, точки роста / Ю. А. Злобин. Сумы : Университет. кн., 2009. - 263 с.

11. Galbraith-Kent S. L. Invasive Acer platanoides inhibits native sapling growth in forest understorey communities / S. L. Galbraith-Kent, S. N. Handel // Brit. Ecol. Society. - 2008. - Vol. 96. - P. 293-302.

12. Martin P. H. Norway maple (Acer platanoides) invasion of a natural forest stand: understory consequence and regeneration pattern / P. H. Martin // Biol. Invas. - 1999. - Vol. 1, № 1-2. - P. 215-222.

13. Reinhart K. O. Facilitation and inhibition of seedlings of an invasive tree (Acer platanoides) by different tree species in a mountain ecosystem / K. O. Reinhart, F. T. Maestre, R. M. Callaway // Biol. Invas. - 2006. - Vol. 8, № 2. - P. 231-240.

14. Кохно Н. А. Клены Украины / Н. А. Кохно. - Киев : Наук. думка, 1982. - 183 с.

15. Букштынов А. Д. Клен / А. Д. Букштынов. - М. : Лесная пром., 1982. - 85 с.

16. Чистякова А. А. Поливариантность онтогенеза и типы поведения деревьев широколиственных лесов / А. А. Чистякова // Популяционная экология растений. - М., 1987. - С. 39-43.

17. Восточноевропейские широколиственные леса / [Р. В. Попадюк, А. А. Чистякова, С. И. Чумаченко [и др.]. М. : Наука, 1994. - 363 с.

Дегтярёв Владислав. Структура популяций клена остролистрого в условиях Кролевецко-Глуховского геоботанического района. Рассмотрена онтогенетическая структура ценопопуляций Acer platanoides в девяти сообществах лесной растительности, типичных для Кролевецко-Глуховского геоботанического района. Определены характерные признаки онтогенетических спектров Acer platanoides в условиях этого района.

Ключевые слова: лесные фитоценозы, популяции, клен остролистый, Кролевецко-Глуховский геоботанический район. 
Dehtiarov Vladislav. Considered Ontogenetic Structure Cenopopulations. Acer platanoides in nine forest phytocenoses, typical of the Krolevetsky-Glukhovski geo-botanical districts. Characteristic features of Acer platanoides ontogenetic spectrum in terms of this district.

Key words: forest phytocenosises population, Acer platanoides, Krolevetsky-Glukhiv geobotanic region.

Стаття надійшла до редколегії 26.11.2015 p.

УДК 574.3. 3.504

Ігор Коваленко

\section{Особливості популяційної організації домінантів трав'янистого ярусу лісових екосистем Національного природного парку «Деснянсько-Старогутський» (на основі віталітетного аналізу)}

Віталітетна структура популяції - це її важлива характеристика. Дослідженнями охоплено популяції п’яти видів рослин лісових екосистем Національного природного парку «Деснянсько-Старогутський»: Aegopodium podagraria L., Asarum europaeum L., Carex pilosa Scop., Molinia caerulea (L.) Moench., Stellaria holostea L. Порівняльний аналіз віталітетної структури популяцій клоноутворювальних рослин трав'янистого ярусу в лісових асоціаціях засвідчує, що їхні віталітетні спектри широко варіюють, а це вказує на чутливість віталітетної структури популяцій до еколого-ценотичних умов й обумовлює високу інформативну цінність віталітетного аналізу. Одержані оцінки віталітетної структури популяцій досліджуваних видів, які є домінантами в лісових екосистемах Національного природного природного парку «Деснянсько-Старогутський», можуть бути вихідними показниками під час організації моніторингу в цьому національному парку та для порівняння стану популяцій до уведення режиму заповідності та після.

Ключові слова: лісові екосистеми, віталітетний аналіз, популяції.

Постановка наукової проблеми та їі значення. Теоретичні основи й алгоритм віталітетного аналізу сформульовано Ю. А. Злобіним [4]. Віталітетний аналіз має на меті оцінку життєздатності особин рослин на основі морфогенетичних ознак із подальшим установленням співвідношення в популяції кількості особин різної життєздатності. В основі віталітетного аналізу лежить ідея про те, що продукційний процес, ріст і морфологічна структура особини, виявлені в кількісних оцінках, дають узагальнену оцінку їі життєвого стану.

Віталітетна структура популяції - важлива характеристика. В останні десятиріччя віталітетний аналіз усе ширше застосовують у популяційних дослідженнях і він виявляється високоінформативним щодо стану популяцій рослин $[1,7,9]$.

Г. Г. Жиляєв та I. В. Царик [3] справедливо відзначали, що «здатність до модифікації онтогенезу виступає найважливішим механізмом забезпечення стійкості популяцій». За рахунок цієї модифікації морфологічної структури особин рослин змінюються їхні віталітетні стани, що робить аналіз віталітетної структури популяцій найціннішим інструментом для індикації їхнього статусу в різних угрупованнях. Віталітетний аналіз дав змогу також ефективно порівнювати стан різних популяцій між собою [5].

Мета й завдання статті. Мета досліджень - визначення віталітетного стану популяцій рослин трав' янистого ярусу з подальшим їх порівнянням.

Головні завдання статті: а) зібрати базу даних морфометричних вимірювань рослин із різних фітоценозів; б) на основі отриманих даних провести віталітетний аналіз і визначити стан та структуру популяцій досліджуваних видів; в) здійснити порівняльний аналіз за показниками віталітету для популяцій із різних фітоценозів.

Виклад основного матеріалу й обгрунтування отриманих результатів дослідження. Дослідженнями охоплено популяції п’яти видів рослин лісових екосистем Національного природного парку

(C) Коваленко I., 2015 